\title{
Numerical study for the spray characteristics of diesel engine powered by biodiesel fuels under different injection pressures
}

\author{
Mohamed F. Al-Dawody*, Khaled A. Al-Farhany, Naseer H. Hamza and Dhafer A. Hamzah \\ Department of Mechanical Engineering, University of Al-Qadisiyah, Al-Qadisiyah, Iraq \\ * Corresponding Author: rukia612010@gmail.com
}

Submitted : 28/02/2020

Revised :08/10/2020

Accepted : 19/10/2020

\begin{abstract}
Great attention is directed towards the study of the spray phenomenon theoretically and experimentally due to its dramatic effect on the combustion process that occurred in an internal combustion engine, in particular, the diesel engine. The spray macroscopic characteristic of diesel engines fueled with two different biodiesel fuels in addition to nominal diesel under various injection pressures has been investigated numerically in this work. The selected biofuels are rapeseed methyl ester (RME) and waste cooking oil methyl ester (WCOME). The Russian simulation software Diesel-RK is used in this work. Four different injection pressures are used, which are 200, 500, 800, and 1000 bar, respectively. It is found that RME has higher spray penetration with a narrow spray angle due to high viscosity and large momentum compared to diesel fuel. The results reported that biodiesels have greater Sauter mean diameter (SMD) compared to pure diesel because of their higher viscosity and surface tension. Promising reduction in SMD comes with WCOME as the injection pressure increases. Cylinder pressure along with heat release is reduced in the case of biodiesel due to the reduction in heating values. The lowest ability to produce smoke is recorded for WCOME, where $93 \%$ reduction is achieved followed by a $57 \%$ reduction for RME as compared to diesel. The obtained results are compared with the results of other researchers, and the convergence between them is observed.
\end{abstract}

Keywords: Spray characteristics; Biodiesel fuel; Diesel engine; Injection pressure; Diesel-RK.

NOMENCLATURE

\begin{tabular}{|c|l|c|}
\hline Symbol & \multicolumn{1}{|c|}{ Definition } & Units \\
\hline $\mathrm{A}_{0}, \mathrm{~A}_{2}, \mathrm{~A}_{3}$ & Constants. & - \\
\hline$A^{-}$ & empirical factor & - \\
\hline $\mathrm{A}_{\mathrm{s}}$ & Empirical coefficient & $\mathrm{m}$ \\
\hline$b_{m}$ & The forward spray depth & $\mathrm{g} / \mathrm{kWh}$ \\
\hline BSFC & Brake specific fuel consumption & \multicolumn{1}{|c|}{} \\
\hline
\end{tabular}




\begin{tabular}{|c|c|c|}
\hline$B_{s}$ & Experimental coefficient. & - \\
\hline$C_{m}$ & empirical coefficient & - \\
\hline $\mathrm{m}_{\mathrm{f}}$ & Mass of fuel & $\mathrm{kg}$ \\
\hline $\mathrm{Nu}_{\mathrm{d}}$ & Nusselt number & - \\
\hline $\mathrm{C}_{\mathrm{d}}$ & Discharge coefficient & - \\
\hline$[\mathrm{C}]$ & Soot concentration in the cylinder & $\mathrm{m}^{3}$ \\
\hline$C_{s}$ & the experimental coefficient & - \\
\hline${ }^{\circ} \mathrm{CA}$ & Crank angle degree & - \\
\hline $\mathrm{CN}$ & Cetane number of fuel & - \\
\hline $\mathrm{C}_{\mathrm{PM}}$ & Empirical factor for PM emission. & - \\
\hline $\mathrm{C}_{\mathrm{NO}}$ & Empirical factor for NOx emission & - \\
\hline $\mathrm{DF}$ & Diesel fuel & - \\
\hline $\mathrm{D}_{\mathrm{s}}$ & Empirical coefficient & - \\
\hline $\mathrm{D}_{\mathrm{p}}$ & Fuel diffusion coefficient & - \\
\hline$D_{p o}$ & diffusion coefficient & - \\
\hline$D_{n}$ & Nozzle diameter & $\mathrm{m}$ \\
\hline$d_{32}$ & Sauter mean diameter & $\mathrm{m}$ \\
\hline$d_{o}$ & the current fuel droplet diameter & $\mathrm{m}$ \\
\hline$d_{k}$ & the initial fuel droplet diameter & $\mathrm{m}$ \\
\hline $\mathrm{E}_{\mathrm{a}}$ & Apparent activation energy for the auto ignition process & $\mathrm{kJ} / \mathrm{kmol}$ \\
\hline EGT & Exhaust gas temperature & ${ }^{\circ} \mathrm{C}$ \\
\hline EGR & Exhaust gas ratio & $\%$ \\
\hline$E_{k}$ & the experimental coefficient & - \\
\hline$E_{S}$ & experimental coefficient & - \\
\hline FP & Friction power & $\mathrm{kW}$ \\
\hline$F_{\text {Sw }}$ & empirical parameter & - \\
\hline G & Acceleration & $\mathrm{m} / \mathrm{s}^{2}$ \\
\hline $\mathrm{H}_{\mathrm{a}}$ & Pressure drop across the orifice & $\mathrm{m}$ \\
\hline$h_{w f r}$ & Height of the dense front of the NWF & $\mathrm{m}$ \\
\hline $\mathrm{h}_{\mathrm{clr}}$ & $\begin{array}{l}\text { Current clearance between the piston and head of the } \\
\text { cylinder }\end{array}$ & $\mathrm{m}$ \\
\hline $\mathrm{K}$ & the constant of evaporation & - \\
\hline $\mathrm{K}_{\mathrm{T}}$ & Evaporation constant & - \\
\hline
\end{tabular}




\begin{tabular}{|c|c|c|}
\hline $\mathrm{L}$ & $\begin{array}{l}\text { the current distance between the EFM and the nozzle } \\
\text { injector }\end{array}$ & $\mathrm{m}$ \\
\hline $1_{\mathrm{a}}$ & The length of the spray at the initial phase & $\mathrm{m}$ \\
\hline$l_{\mathrm{b}}$ & The length of the spray at the main phase & $\mathrm{m}$ \\
\hline $1_{\mathrm{m}}$ & the penetration length of EFM till the end in front of a spray & $\mathrm{m}$ \\
\hline $\lg _{\mathrm{g}}$ & The border between main and initial phases & $\mathrm{m}$ \\
\hline Abbreviation & Definition & Units \\
\hline CME & Castor methyl ester & - \\
\hline M & the square ohenzorge number & - \\
\hline $\mathrm{CPF}$ & Control portion of fuel & \\
\hline NWF & Near wall flow & - \\
\hline NOx & Nitrogen oxides & ppm \\
\hline $\mathrm{P}$ & Current pressure in the cylinder & pa \\
\hline $\mathrm{p}_{\mathrm{s}}$ & Saturation pressure & pa \\
\hline $\mathrm{PM}$ & Particulate matter & $\mathrm{g} / \mathrm{kW} \cdot \mathrm{h}$ \\
\hline $\mathrm{R}$ & Universal gas constant & $\mathrm{kJ} / \mathrm{kmol} . \mathrm{K}$ \\
\hline$r_{v}$ & $\begin{array}{l}\text { the rate of the relative evaporation in the front and } \\
\text { environment regions }\end{array}$ & $\%$ \\
\hline$r_{w i}$ & $\begin{array}{l}\text { the rate of the relative evaporation within various areas of the } \\
\text { wall surface flow }\end{array}$ & $\%$ \\
\hline $\mathrm{S}$ & The stroke of the piston & $\mathrm{m}$ \\
\hline SE & Summary of (PM \& NOx emissions) & $\mathrm{g} / \mathrm{kW} \cdot \mathrm{hr}$ \\
\hline $\mathrm{T}$ & Temperature in the cylinder & $\mathrm{K}$ \\
\hline$T_{k}$ & the temperature in the related zone & $\mathrm{K}$ \\
\hline $\mathrm{T}_{\mathrm{z}}$ & Zonal temperature & $\mathrm{K}$ \\
\hline $\mathrm{TDC}$ & top dead center & $\mathrm{m} / \mathrm{s}$ \\
\hline $\mathrm{V}$ & the current speed of the EFM & $\mathrm{m} / \mathrm{s}$ \\
\hline $\mathrm{V}_{0}$ & the initial speed of the EFM at the nozzle injector & $\mathrm{m} / \mathrm{s}$ \\
\hline $\mathrm{V}_{\mathrm{m}}$ & Velocity of the spray's front & $\mathrm{m} / \mathrm{s}$ \\
\hline$V_{m a}$ & The spray head speed is calculated in the initial stage & $\mathrm{m} / \mathrm{s}$ \\
\hline$V_{m b}$ & The spray head speed is calculated in the basic stage & $\mathrm{m} / \mathrm{s}$ \\
\hline $\mathrm{Vc}$ & Cylinder volume & $\mathrm{m}^{3}$ \\
\hline
\end{tabular}




\begin{tabular}{|c|c|c|}
\hline$V_{\text {om }}$ & the mean speed of the nozzle spray & $\mathrm{m} / \mathrm{s}$ \\
\hline$W_{e}$ & the Weber Number & - \\
\hline $\mathrm{X}$ & Fraction of heat release & - \\
\hline $\mathrm{x}_{\mathrm{o}}$ & $\begin{array}{l}\text { Fraction of the fuel vapor formed during ignition delay and } \\
\text { burnt out. }\end{array}$ & - \\
\hline \multicolumn{3}{|c|}{ Greek Symbols } \\
\hline$\rho$ & dimensionless density & - \\
\hline$\rho_{f}$ & the fuel density & $\mathrm{Kg} / \mathrm{m}^{3}$ \\
\hline$\rho_{\text {air }}$ & air density & $\mathrm{Kg} / \mathrm{m}^{3}$ \\
\hline$\Sigma$ & Fraction of the fuel injected into the cylinder & $\%$ \\
\hline$\sigma_{\text {core }}$ & Fuel part of the dense heart & - \\
\hline$\sigma_{f}$ & coefficient of the surface tension of the fuel & - \\
\hline$\sigma_{s}$ & fractions of fuel injected into cylinder at time $\tau_{s}$ & - \\
\hline$\sigma_{k}$ & fractions of fuel injected into cylinder at time $\tau_{k}$ & - \\
\hline$\sigma_{\mathrm{u}}$ & Fraction of the vapor formed during the ignition period. & $\%$ \\
\hline$\sigma_{z i}$ & part of fuel in any area & - \\
\hline $\mathrm{T}$ & Ignition delay & second \\
\hline$\tau_{g}$ & The boundary between the two phases is noted as time & second \\
\hline$\tau_{k}$ & $\begin{array}{l}\text { travel period for the EFM to amount to the length } l \text { from the } \\
\text { nozzle injector }\end{array}$ & second \\
\hline$\tau_{m}$ & $\begin{array}{l}\text { travel period for the EFM to amount to the spray's front } \\
\text { before ending }\end{array}$ & second \\
\hline$\tau_{s}$ & current time from fuel injection at the beginning & second \\
\hline$\tau_{\text {soi }}$ & current time when the entry of fuel & second \\
\hline$\tau_{u}$ & $\begin{array}{l}\text { the current time when the droplet being inside the combustion } \\
\text { chamber within the characteristic zone }\end{array}$ & second \\
\hline$\mu_{f}$ & fuel dynamic viscosity & pa.s \\
\hline$\Theta$ & Crank angle & degree \\
\hline$\phi$ & Equivalence ratio & - \\
\hline$\varphi$ & dimensionless parameter & - \\
\hline$\gamma$ & Adiabatic exponent of exhaust gas & - \\
\hline$\gamma_{a}$ & The cone angle for the spray during the initial stage & degree \\
\hline$\gamma_{b}$ & The cone angle for the spray during the basic phase & degree \\
\hline$\varepsilon_{b}$ & Efficiency of air used. & $\%$ \\
\hline
\end{tabular}




\section{INTRODUCTION}

Recently biodiesel has received more attention all over the world as a renewable energy source. Biodiesel or ester of oil extracted from edible and nonedible seed is found to be one of the best alternatives (Srinidhi, Madhusudhan et al. 2019). Since there is no need to change the fuel system or engine itself, especially if conventional diesel is mixed with a few amounts of biodiesel, this gives biodiesel an advantage to use it more and more although it has different physical and chemical properties compared to those of common diesel. Among these properties are the higher viscosity, surface tension, and density, which have an impact on the characteristics of the spray of biodiesel fuel. The current of research on Compression Ignition engine fuelled with biodiesel has taken ages, but its retarded thermal performance, higher NOx emissions, and fuel consumption have retarded use of biodiesel. One of the ways to control the above drawbacks is to change the engine operating parameters such as compression ratio, injection pressure, and injection timing (Srinidhi and Madhusudhan 2017). The good and effective atomization of spray definitely leads to efficient combustion and consequently to the higher thermal efficiency of the engine.

Different studies listed in the literature are discussed in the next lines. The effects of injection timings as well as split injection on characteristics of a diesel engine powered by cashew nut shell biodiesel blends are experimentally investigated by Senthil kumar and Thirumalini (2020). Smoke is reduced by $19.5 \%$ and $73.8 \%$ for diesel and B5, respectively, at $4^{\circ}$ retarded $\mathrm{CA}$ and $15 \%$ split. It is found that, with retarded injection timing and split injections, lower emissions are attained without affecting the performance for all fuel blends.

An experimental work was investigated by Srinidhi, Madhusudhan et al. (2019) to study the using of exhaust gas recirculation and nanoparticle in biodiesel blends at different injection pressures. A total rise of $17 \%$ brake thermal efficiency was observed with nanoparticle as compared to EGR method. The overall conclusion based on the experimentation highlights that usage of nanoparticles in biodiesel provides much better performance and emission reduction. The type of biodiesel was investigated at high pressure and constant volume in the work of Senatore, Cardone et al. (2005) who studied the effect of ambient pressure on the spray penetration.

Lee, Park et al. (2005) studied the characteristics of atomization of biodiesel, which include spray penetration, SMD, and velocity distribution. It is observed that the biodiesel blended fuels have the same spray penetration compared to neat diesel, and the SMD is higher due to higher surface tension and viscosity of biodiesel compared to ordinary diesel. Zhao, Han et al. (2008) conducted a study to investigate the influence of injection duration as well as ambient pressure on the penetration and angle of the spray using an electronic pump. The study reported that biodiesel has larger spray penetration and spray angle than those of pure diesel.

Grimaldi and Postrioti (2000) investigated the characteristics of spray for diesel fuel blended with biodiesel under high injection pressures. The range of injection pressure is $600-1200$ bars. Some differences in behavior between biodiesel and diesel can be noticed. One important characteristic is the penetration, which by its virtue varies directly to the injection pressure higher and lower for biodiesel and diesel, respectively. Some studies investigated the influence of physical properties like fuel density and viscosity as reported in the works of Ahmed, Ejim et al. (2006) and Ejim, Fleck et al. (2007), where a bigger influence is given to the fuel viscosity. On a related level, the equipment usually used to inject biodiesel or diesel also has attention in the literature whether they are mechanical pump, injector, etc. (Xusheng, Liguang et al. 2007 and Gao, Deng et al. 2009).

Many industrial, agricultural, and pharmaceutical applications involved a system of spray; therefore, the spray phenomena and atomization process have been studied intensively and modeled theoretically and experimentally in many aspects and for different testing regimes (Hiroyasu and Arai 1990). On a related level, the injected fuel in internal combustion engines, which forms a cone spray in the cylinder, also has been studied in terms of its characteristic parameters like cone angle, penetration length, and Sauter mean diameter at different operating 
conditions (Mohan, Yang et al. 2014), (Payri, Payri et al. 2014), (Jia, Li et al. 2016), and (Lacour, Raoult et al. 2019).

Currently, the use of biofuels as an alternative fuel in IC engines has increased because of the environmental impacts of using petroleum fuels.

Spray characteristics strongly affect the combustion process that occurred in the internal combustion engine, in particular, the diesel engine and consequently the emissions resulting from it. Therefore, great attention is directed towards the study of the spray phenomena theoretically and experimentally keeping an eye on the new trend in using biofuels as a working fuel in two forms: either pure or blended with conventional fuels due to its merits as an environmentally friendly fuel.

Biodiesel is one of the best alternative fuels for diesel engines. It can be used without making engine modification because of its similar properties to that of neat diesel. However, studying the behavior of fuel spray is important as it affects the characteristics of combustion and emissions as well. A numerical model is utilized in this work to study the characteristics of spray with a special focus on spray penetration, spray cone angle, and SMD.

The simulation models of diesel engines are sorted into three categories: single-zone model, multizone model, and multidimensional model (Jung and Assanis 2001). The zero-dimensional single-zone model assumes "that cylinder charge is uniform in composition and temperature at all times during the cycle." The single-zone model weakly focuses the spray evolution as well as the variations in composition and temperature, which are necessary for exhaust emissions prediction. In addition to single-zone model, there is the two-zone model, in which there are unburnt zone and burnt zone. In spite of the differences in the nature of the combustion process in S.I. and C.I. engines, the two-zone model can still be used for both types since it is basically a zero-dimensional model that considers only burned and unburned zones without any consideration of the spatial location of such zones. On the other hand, a multidimensional model resolves cylinder space into fine grids (Bracco 1985). However, the accuracy of the results cannot be guaranteed.

In this paper, the macroscopic characteristics of spray with a special focus on spray penetration, spray cone angle, and Sauter mean diameter of different biofuels subjected to variable injection pressures investigated numerically using the Russian numerical software Diesel-RK. The combustion and emission parameters are analyzed as well.

\section{PROPERTIES OF DIESEL AND BIOFUELS}

The physical and chemical properties of fuels under study have been inserted into the Diesel-RK library and listed in Table (1). The numerical simulation is carried out on the engine, which has the technical specifications reported in Table (2).

Table 1. Properties of diesel RME and MEWCO (Al-Dawody 2017) and (Al-Dawody, Jazie et al. 2019).

\begin{tabular}{|c|c|c|c|}
\hline Property & Diesel & RME & WCOME \\
\hline $\mathrm{C}$ & 0.87 & 0.85 & 0.77 \\
\hline $\mathrm{H}$ & 0.126 & 0.125 & 0.121 \\
\hline $\mathrm{O}$ & 0.004 & 0.025 & 0.109 \\
\hline Density at $15^{\circ} \mathrm{C}\left(\mathrm{kg} / \mathrm{m}^{3}\right)$ & 830 & 839 & 870 \\
\hline
\end{tabular}




\begin{tabular}{|c|c|c|c|}
\hline Viscosity at $40{ }^{\circ} \mathrm{C}(\mathrm{cst})$ & 3.0 & 3.4 & 4.9 \\
\hline Calorific value $(\mathrm{MJ} / \mathrm{kg})$ & 45.83 & 42.04 & 40.20 \\
\hline Flash point $\left({ }^{\circ} \mathrm{C}\right)$ & 76 & 87 & 130 \\
\hline Cetane number & 48 & 48.6 & 51 \\
\hline Molecular weight & 190 & 211.2 & 296 \\
\hline
\end{tabular}

Table 2. Engine specifications (Al-Dawody, Jazie et al. 2019).

\begin{tabular}{|c|c|}
\hline Brand of Engine & Kirloskar Diesel Engine \\
\hline Kind & 1-Cylinder, 4-Stroke \\
\hline Bore & $80 \mathrm{~mm}$ \\
\hline Stroke & $110 \mathrm{~mm}$ \\
\hline Ratio of compression & 17.5 \\
\hline Brake power & $3.7 \mathrm{~kW}$ \\
\hline R.P.M & 1500 \\
\hline Injection pressure & Variable (200-1000) bar \\
\hline Injection timing SOI & 20 CA BTDC \\
\hline Fuel injection nozzle & 0.16 \\
\hline
\end{tabular}

\section{THE SIMULATION SOFTWARE DIESEL-RK}

DIESEL-RK simulation program is engineered to optimize and evaluate four or two stroke internal combustion engines. This program represents a class of thermodynamic simulation programs. This means that this program treats engine cylinders as an open thermodynamic system. The program has numerous excellent features; some of them are used and listed as follows (Al-Dawody 2013):

1- The potential to optimize the piston bowl shape and the parameters of the fuel injection system to develop multiple injection strategies and common rail controlling algorithms within the whole operating range.

2- The potential to use multipara metric optimization and thermodynamic analysis of the fuel injection systems and valve timing.

3- The program allows the user to select different optimization techniques for one-, two-, and multidimensional problems to reduce any increment in the emissions of the nitrogen oxides.

4- The ability to support different fuel libraries that include multiple mixtures of diesel fuel with biodiesels. The properties defined by the user can be saved in the database of the program.

5- The potential to use coding to predict and optimize combustion process in diesel engine. The program includes the fuel spray visualization code, which can be used for the analysis of the fuel sprayer showing its animation image and development. 


\section{NUMERICAL SIMULATION}

The pursuit of efficient and low emission diesel engines leads researchers always to seek powerful tools that can grant a better understanding of the whole process of operation of the engine at different operation scenarios. Many simulation software devices are used nowadays and among them is Diesel-RK, which is considered to be one of the best simulation software devices regarding internal combustion engines.

\section{Spray Evolution Model}

The multizone combustion model is used in this work (Kuleshov 2005). The basic model is based on the fact of division of the injected spray into different zones (Kuleshov, Mahkamov et al. 2008). The location and velocity of $\mathrm{CPF}$ are given as

$$
\left(\frac{U}{U_{o}}\right)^{3 / 2}=1-\frac{l}{l_{m}}
$$

The equation can be solved to get

$3 l_{m}\left[1-\left(1-\frac{l}{l_{m}}\right)^{0.333}\right]-U_{o} t_{k}=0$

Figure 1 displays a spray in a simplified way.

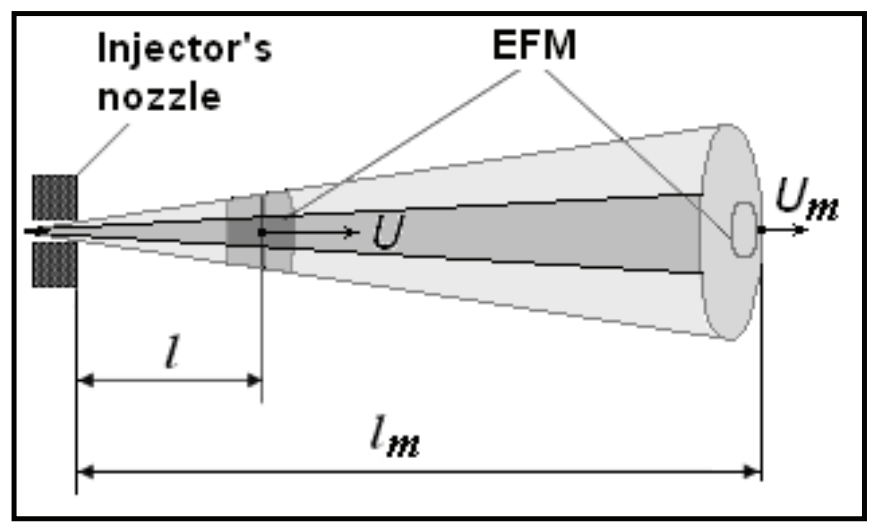

Figure 1. Spray development in a simplified way (Kuo and Bracco 1982).

Equation 2 is rearranged as follows:

$$
l_{m}=U_{o} \frac{t_{m}}{3}
$$


The current velocity and distance of CPF can be obtained as

$U=U_{o}\left(1-\frac{t_{k}}{t_{m}}\right)^{2}$
$l=l_{m}\left[1-\left(1-\frac{t_{k}}{t_{m}}\right)^{3}\right]$

Different parameters based on dimensionless form were used to find out the spray geometry as follows:

$W e=U_{o m}^{2} d_{n}$

$M=\frac{\mu_{f}^{2}}{\left(\rho_{f} d_{n} \sigma_{f}\right)}$

$\Phi=\frac{t_{s}^{2} \sigma_{f}}{\left(\rho_{f} d_{n}^{3}\right)}$

$\rho^{-}=\frac{\rho_{\text {air }}}{\rho_{\text {fuel }}}$

The development fuel spray happens within two phases, initially denoted by $a$ and main phase denoted by $b$. The transition between these two phases is denoted by $g$. Kuleshov, Mahkamov et al. (2008) suggested two parameters as follows:

$l_{g}=C_{s} d_{n} W e^{0.25} M^{0.4}\left(\rho^{-}\right)^{-0.6}$

$t_{g}=\frac{l_{g}^{2}}{B_{s}}$

where $B_{s}$ is the empirical coefficient given by

$B_{s}=d_{n} U_{o m} W e^{0.21} \frac{M^{0.16}}{\left(D_{s} \sqrt{2} \rho^{-}\right)}$

The spray length and spray angle at initial phase $\left(l_{a}\right.$ and $\left.\gamma_{a}\right)$ and main $\left(l_{b}\right.$ and $\left.\gamma_{b}\right)$ s are determined as 


$$
\begin{aligned}
& l_{a}=A_{s} \Phi^{0.35} \exp \left[-0.2\left(\frac{t_{s}}{t_{g}}\right)\right] \\
& \gamma_{a}=2 \times \operatorname{arctg}\left(E_{s} W e^{0.35} M^{-0.07} \Phi^{-0.12} \rho^{0.5} e^{0.07 t_{s} / t_{g}}\right)
\end{aligned}
$$

while the spray length and its angle are determined as

$$
\begin{aligned}
& l_{b}=B_{s}^{0.5} t_{s}^{0.5} \\
& \gamma_{b}=2 \times \operatorname{arctg}\left(F_{s} W e^{0.32} M^{-0.07} \Phi^{-0.12} \rho^{0.5}\right)
\end{aligned}
$$

The empirical coefficients $A_{s}$ and $E_{s}$ are calculated as follows:

$$
\begin{aligned}
& A_{s}=1.22 l_{g} \Phi_{g}^{-0.35} \\
& E_{s}=0.932 F_{s} W e^{-0.03} \Phi_{g}^{0.12}
\end{aligned}
$$

A similar equation was reported by Kuo and Bracco (1982). Equations (10) to (16) are valid for nozzle diameters greater than $0.3 \mathrm{~mm}$. For smaller than 0.3 , the following expression for $D_{s}$ is used:

$$
D_{s}=\frac{14.21}{D_{f}}
$$

where

$$
D_{f}=\left\{\begin{array}{l}
2.9, \quad \text { if } \quad d_{n} \geq 0.3 \\
2.9\left(9.749 d_{n}^{3}+7.45 d_{n}^{2}-7.21 d_{n}+2.224\right) \quad \text { if } \quad d_{n} \prec 0.3
\end{array}\right\}
$$

The latter equations are obtained from (Arrègle, Pastor et al. 1999), (Pastor, Encabo et al. 2000), (Larmi, Rantanen et al. 2002), and (Nakagawa, Oda et al. 1990).

The spray tip velocity at the initial phase $\left(U_{m a}\right)$ and basic phase $\left(U_{m b}\right)$ are calculated with the following empirical expressions:

$$
\begin{aligned}
& U_{m a}=l_{a}\left(0.7 / t_{s}-0.2 / t_{g}\right) \\
& U_{m b}=0.5 l_{b} / t_{s}
\end{aligned}
$$




\section{Fuel Evaporation Model}

The model of evaporation used in this work is based on the assumptions below (Hiroyasu 1980):

2.1 Zonal evaporation speed equals the total fuel droplets speeds. It can be found from

$$
d_{k}^{2}=d_{o}^{2}-K \cdot t_{u}
$$

The equation of Sauter is used the average diameter of droplets as follows:

$d_{32}=E_{k} d_{n} M^{0.0733}(\text { We. } \rho)^{-0.266}$

The droplet initial diameter mentioned in (Equation 29) is equal to Sauter mean diameter.

$d_{0}=d_{32}$

2.2. During the entire fuel injection process, the ratio $K / d_{o}{ }^{2}=b_{u}$ is constant. The zonal relative speed can be calculated as

$$
\begin{aligned}
\frac{d \sigma_{u i}}{d t} & =\left[1-\left(1-b_{u i} t_{u i}\right)^{3 / 2}\right] \frac{\sigma_{z i}}{t_{u i}} \\
t_{u i} & =t_{s}-t_{s o i}
\end{aligned}
$$

Each zone has its constant evaporation, which can be determined as

$K_{u i}=4 \times 10^{6} N u_{D} D_{p} \frac{p_{s}}{\rho_{f}}$

The diffusion coefficient can be determined as

$$
D_{p}=D_{p o}\left(\frac{T_{k}}{T_{o}}\right)^{3 / 2}\left(\frac{p_{o}}{p}\right)
$$

\section{Heat Release Model}

Four stages of combustion are mentioned below:

3.1. Delay time

$$
\tau=3.8 * 10^{-6}\left(1-1.6^{*} 10^{-4} . n\right) \sqrt{\frac{T}{P}} \cdot \exp \left(\frac{E_{a}}{8.312 T}-\frac{70}{C N+25}\right)
$$


$\frac{d x}{d t}=\varphi_{o}\left(A_{o}\left(m_{f} / V_{i}\right) \cdot\left(\sigma_{u d}-x_{o}\right) \cdot\left(0.1 \sigma_{u d}+x_{o}\right)\right)+\varphi_{1}\left(d \sigma_{u} / d t\right)$

(31)

3.3 Controlled combustion

$\frac{d x}{d t}=\varphi_{1}\left(d \sigma_{u} / d t\right)+\varphi_{2}\left(A_{2}\left(m_{f} / V\right) \cdot\left(\sigma_{u}-x\right)(\phi-x)\right)$

3.4. Combustion tail

$\frac{d x}{d t}=\varphi_{3} A_{3} K_{T}(1-x)\left(\xi_{b} \cdot \phi-x\right)$

$\varphi_{0}=\varphi_{1}=\varphi_{2}=\varphi_{3}$ is a function describing completeness of fuel vapor combustion in the zones:

$\varphi=1-\frac{A_{1}}{\zeta_{b} \phi-x}\left\{r_{v}+\sum_{i=1}^{m_{w}}\left[300 r_{w i} \exp \left(\frac{-16000}{2500+T_{w i}}\right)\right]\right\} \frac{d x}{d t}$

where $\zeta_{b}$ is the efficiency of air use, $\phi$-equivalence ratio, $r_{v}$-relative evaporation rate in the zones of environment and front, and $r_{W i}$-relative evaporation rate in the different zones of wall surface flow.

\section{MODELING OF SOOT CONCENTRATION}

The particle of soot can be defined as dispersion of black carbon. It forms, grows, and oxidizes because of the chemical reaction that occurs through combustion (Al-Dawody 2006). Full information about soot models is described in (Alkidas 1984). Exhaust soot concentration related to normal conditions is as follows:

$[C]=\int_{\theta_{B}}^{480} \frac{d[C]}{d t} \cdot \frac{d \theta}{6 n}\left(\frac{0.1}{p}\right)^{\gamma}$

$[C]$ - concentration of soot; $\gamma$-ratio of exhaust gases specific heats.

\section{RESULTS AND DISCUSSION}

\section{Model Validity}

The findings/results of this study have been compared with the results of other researchers in the same range of operating conditions. The comparison reflects a nice convergence with a very little difference. Figures 2 and 3 show the pressure of the cylinder and the spray tip penetration versus crank angle. A slight deviation is reported. 


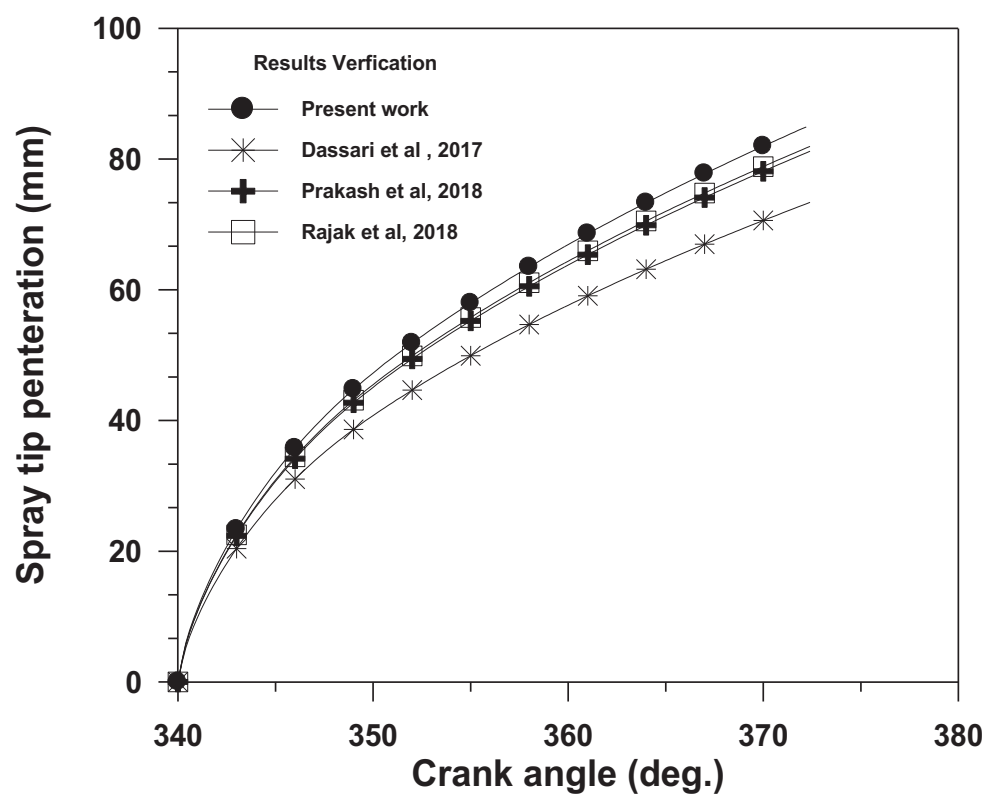

Figure 2. Verification of the spray tip penetration between different research papers.

\section{Spray Tip Penetration}

The physical properties of fuel like density, viscosity, surface tension, etc. and the boundary condition like ambient pressure and temperature play an important role and determine the nature and shape of the fuel spray. In addition to these parameters, the fuel injection pressure has the strongest effect.

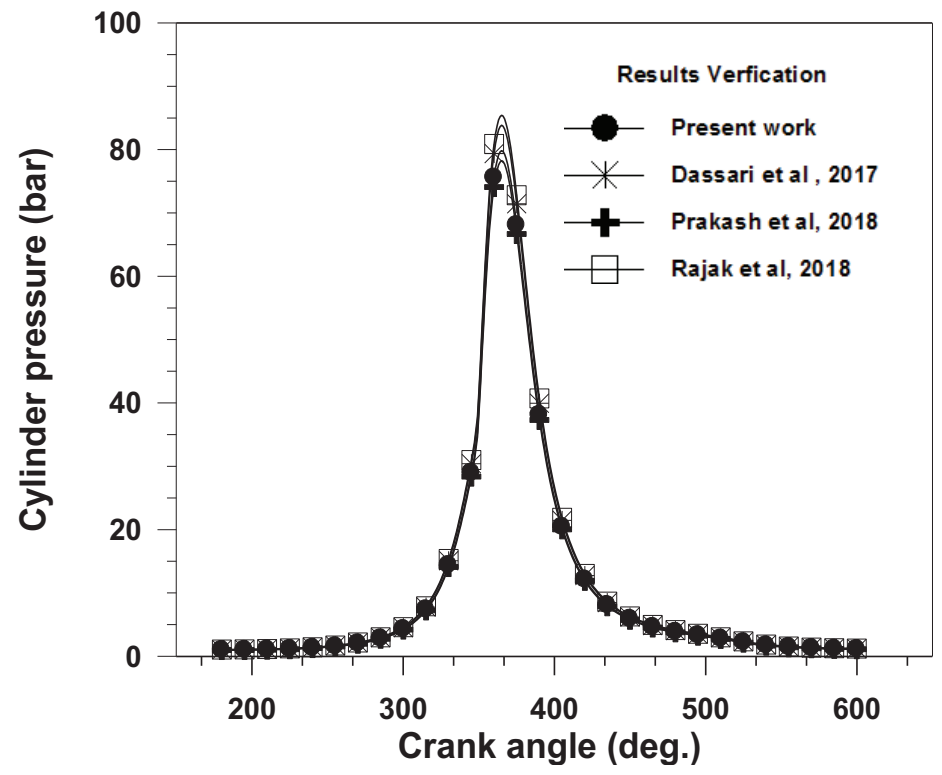

Figure 3. Verification of the cylinder pressure between different research papers. 


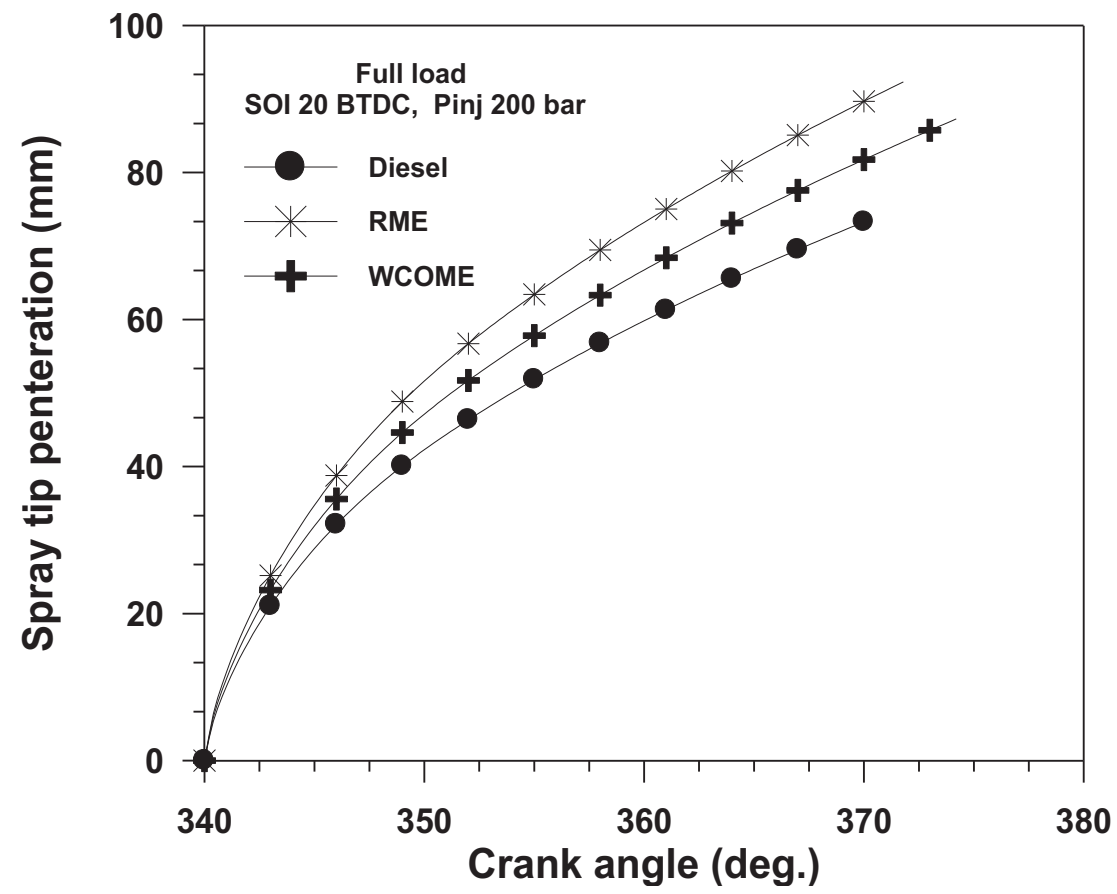

Figure 4. The spray tip penetration with crank angles for different fuels at 200 bar.

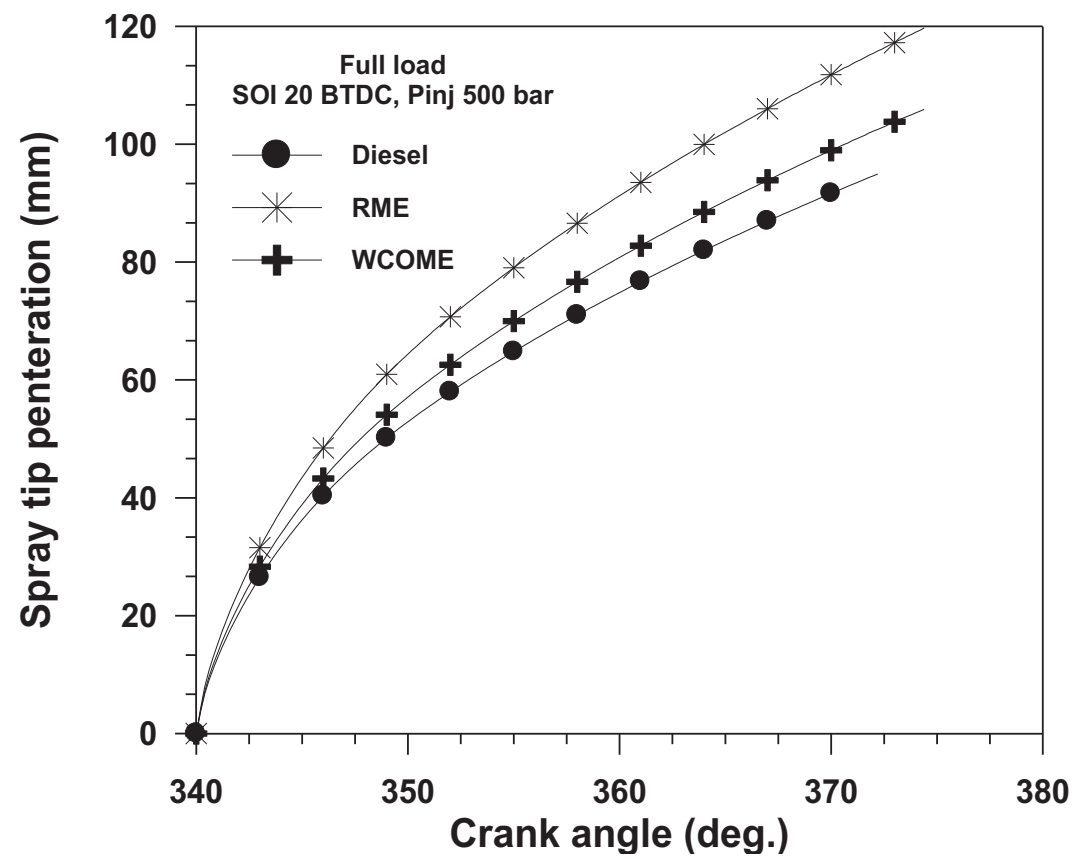

Figure 5. Spray tip penetration with crank angle for different fuels at 500 bar. 


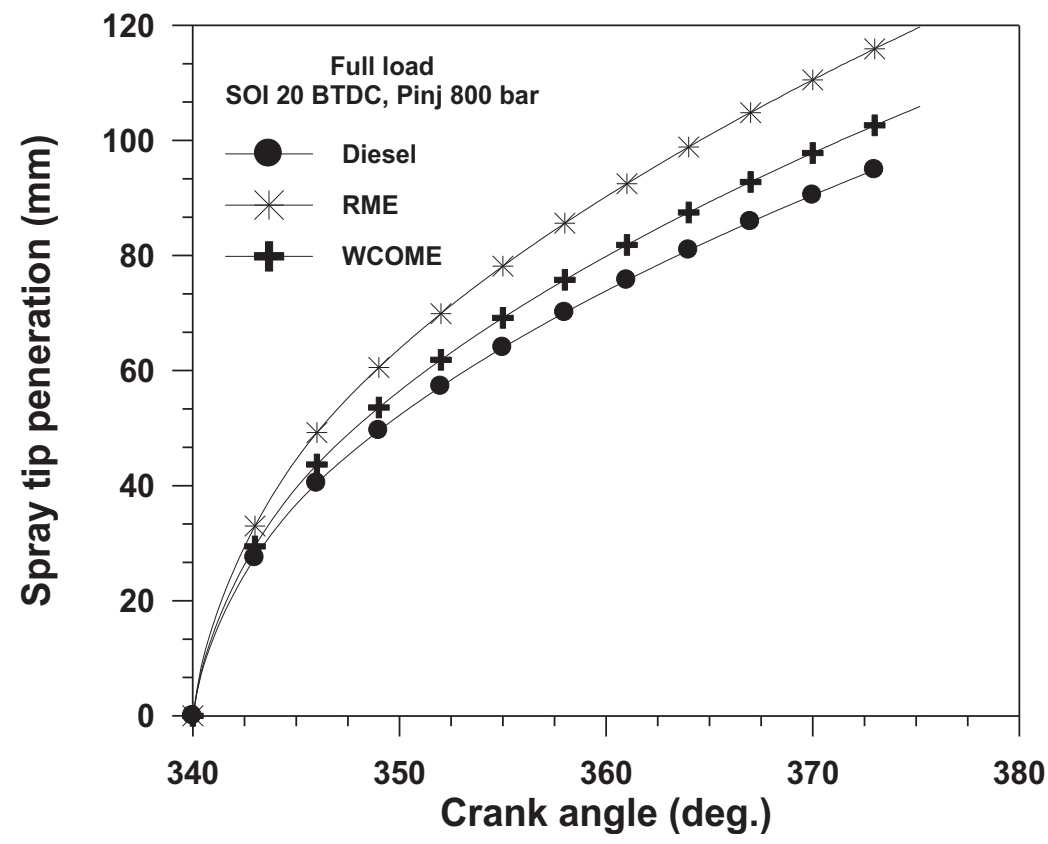

Figure 6. Spray tip penetration with crank angle for different fuels at 800 bar.

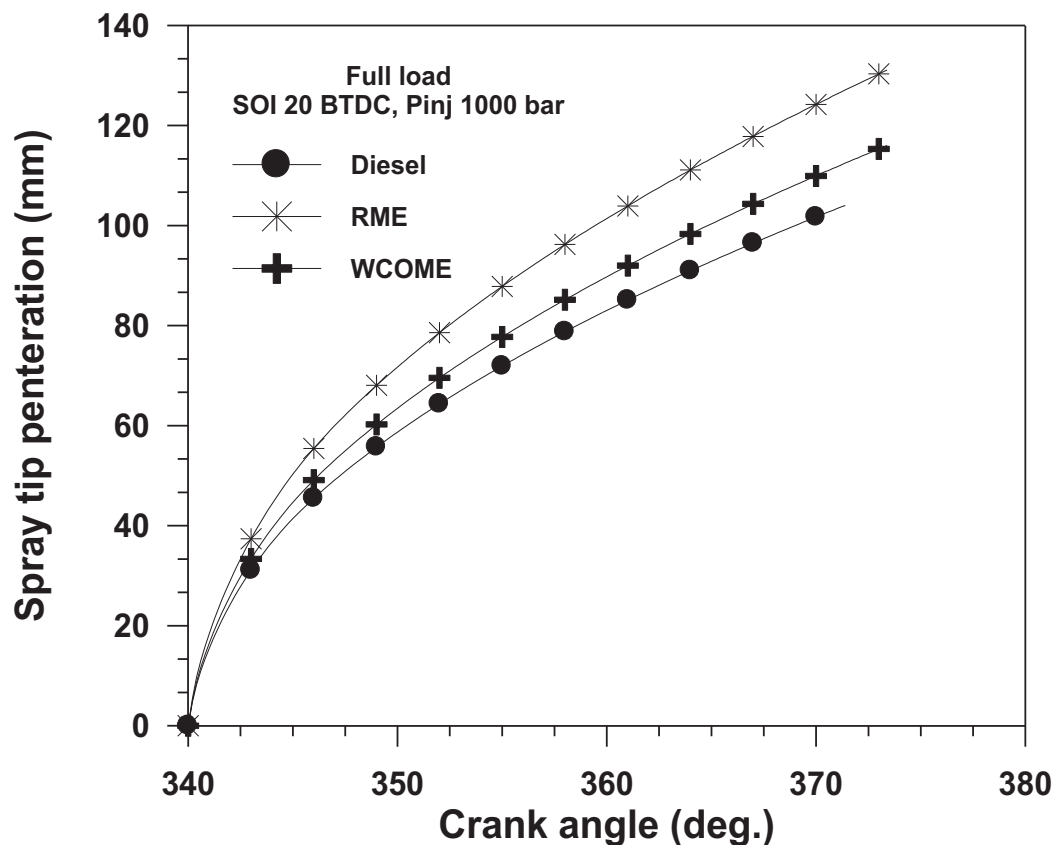

Figure 7. Spray tip penetration with crank angle for different fuels at 1000 bar. 
Figures (4-7) display the spray tip penetration with a crank angle at different injection pressures starting from 200 bar, 500 bar, then 800, and finally 1000 bar. Tested fuels used for the investigations are diesel, RME, and WCOME. A rapid increase in spray penetration is noticed through the initial stages of injection because of less reaction between droplets and nitrogen. RME has a higher spray penetration followed by WCOME; then, diesel comes last. The difference in the density and viscosity levels is responsible for the trend; hence, the spray jet is prevented from breaking, resulting in an increase in the size of the spray droplets (Gao, Deng et al. 2009). The same behavior continues when injection pressure increased. There is a reasonable scenario that explains spray penetration based on the law of conservation of energy, which states that the pressure energy comes from injection pressure directly converts to kinetic energy for fuel particles and thus increases its velocity and penetration. Higher injection pressure means higher kinetic energy and faster movement of spray droplets (Deng, Li et al. 2010). Hence, the spray penetration is lengthened, recording higher penetration for RME $92.32 \mathrm{~mm}$ at $372 \mathrm{CA}$, while it was 73.26 at 370 for diesel. When the injection pressure increases from 200 bar to 1000 bar, spray penetration increases $41 \%, 42 \%$, and $33 \%$ for diesel, RME, and WCOME, respectively.

\section{Spray Cone Angle}

Figures (8-11) show the development of a spray angle with a crank angle for the fuels under investigation at different injection pressures. The viscosity and surface tension are higher for biodiesel than those of diesel fuel as the spray continuous droplets around the border become smaller and diffused easily leading to a reduction in spray angle. At 200 bar, while the spray angle was $41^{\circ}$ for diesel, it was $34.5^{\circ}$ and $35^{\circ}$ for RME and WCOME, respectively.

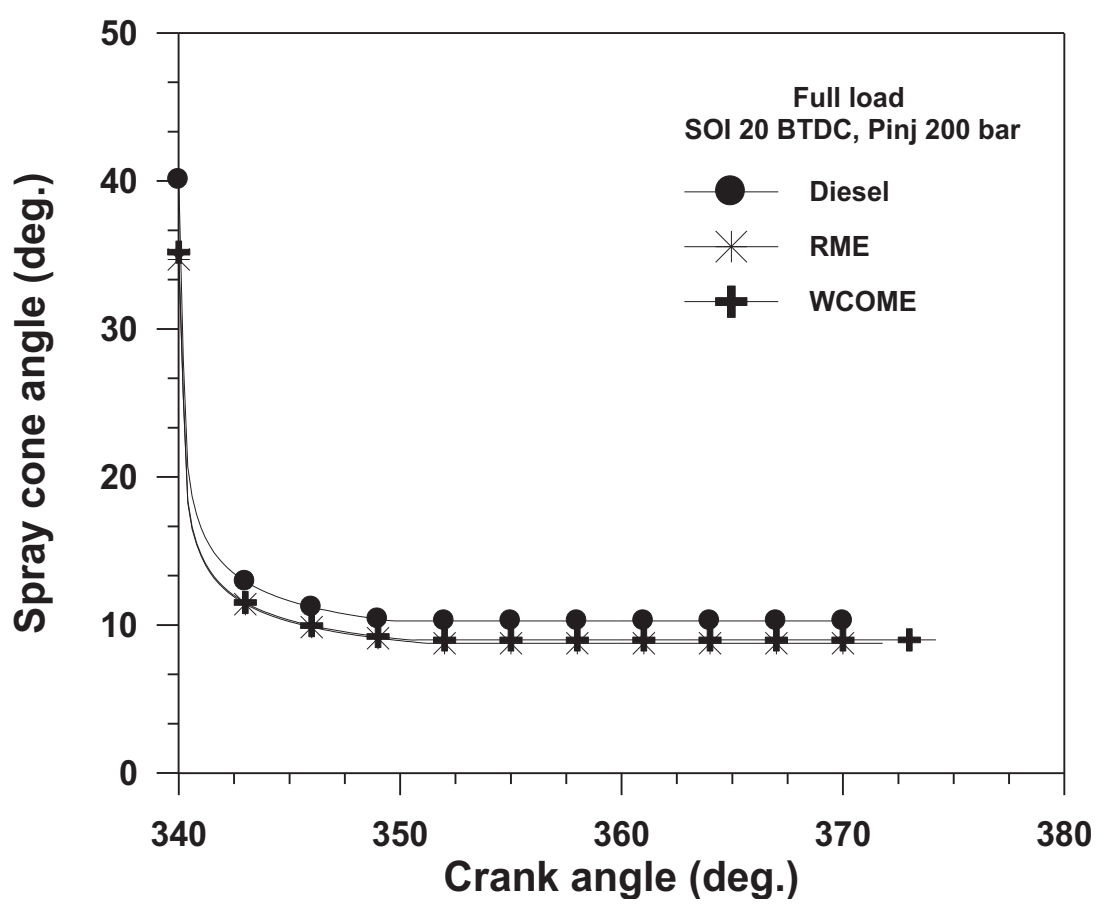

Figure 8. The spray cone angle with crank angle for different fuels at 200 bar. 


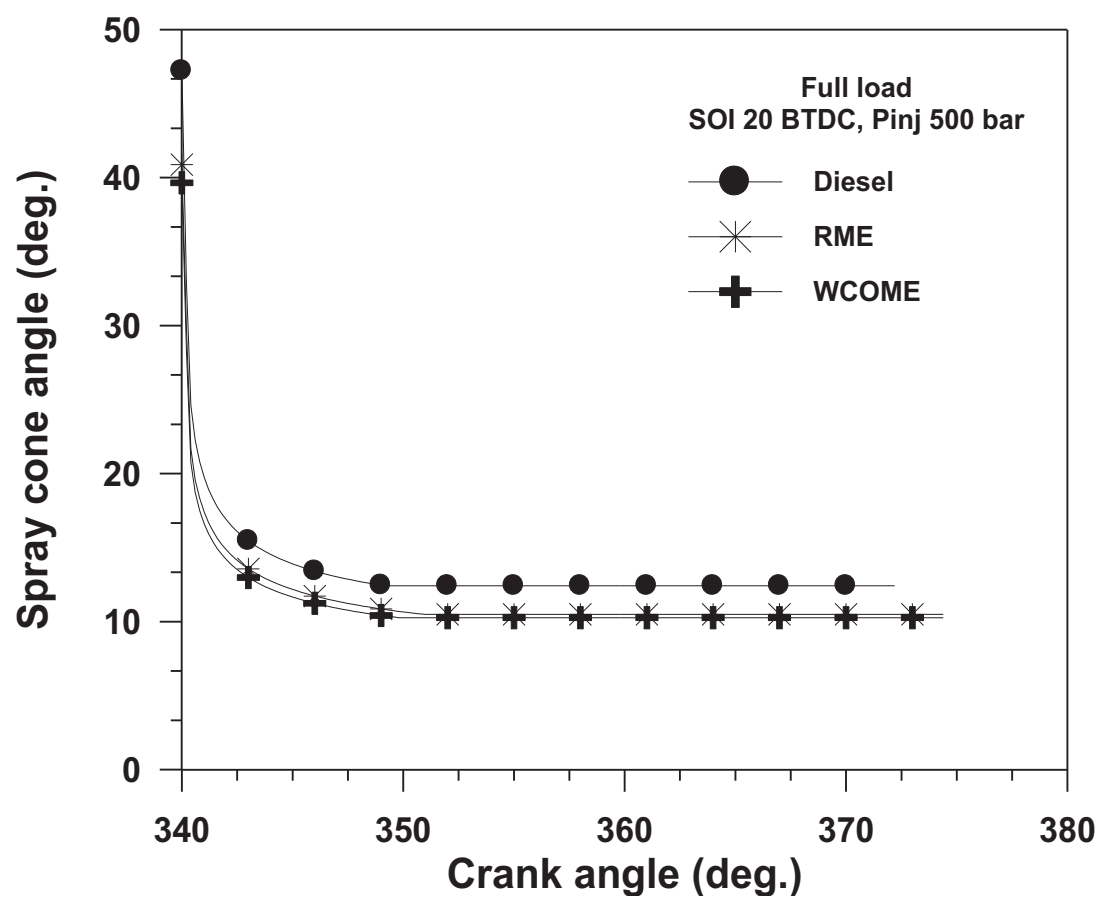

Figure 9. The spray cone angle with crank angle for different fuels at 500 bar.

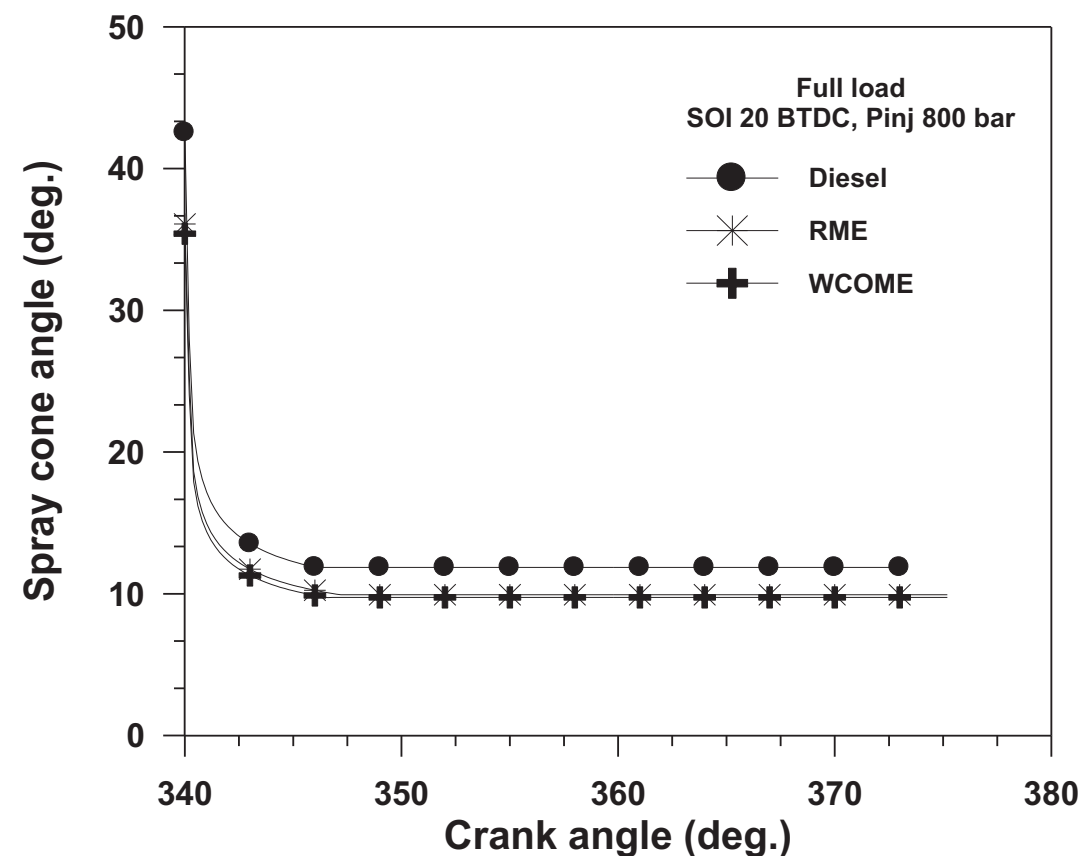

Figure 10. The spray cone angle with crank angle for different fuels at 800 bar. 


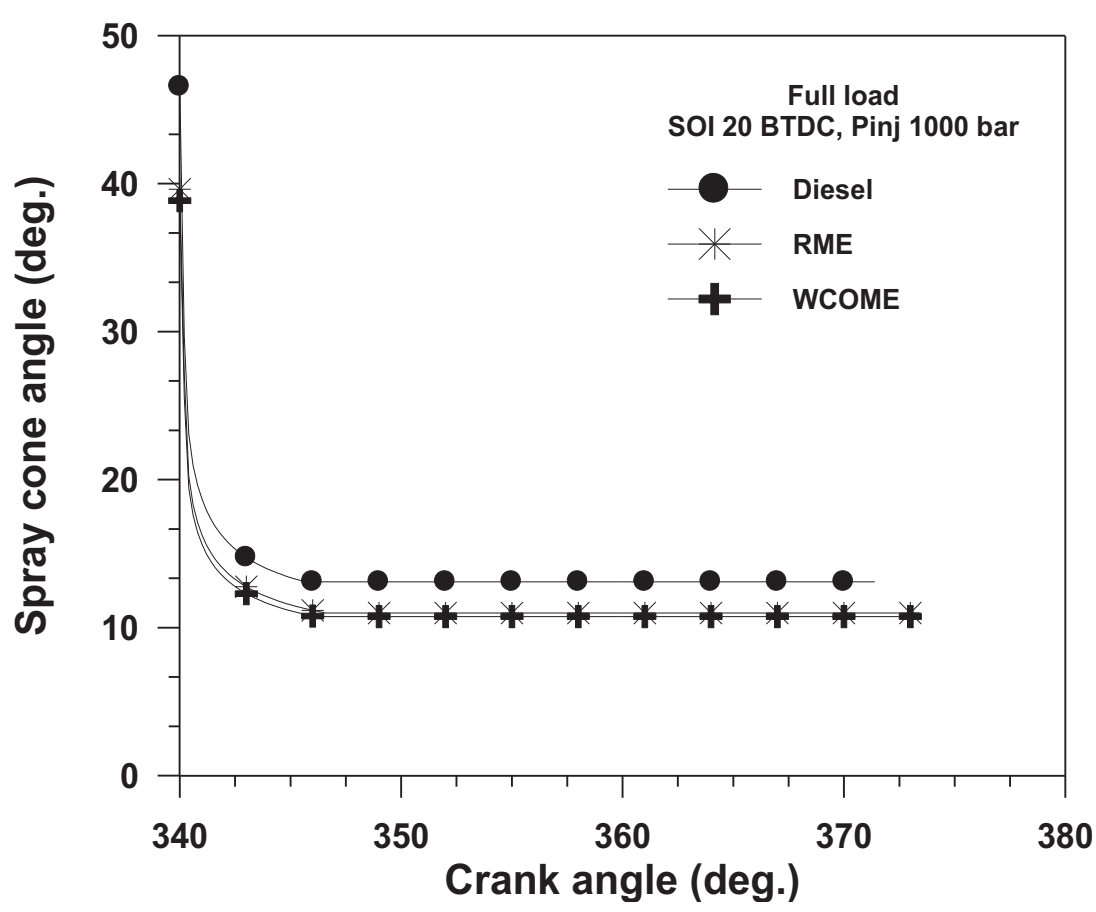

Figure 11. The spray cone angle with crank angle for different fuels at 1000 bar.

The spray pattern is also affected since a dense and viscous fuel tends to induce a longer spray penetration and with a narrower spray angle. The effect of injection pressure on the spray angle is smooth. When the injection pressure increases from 200 bar to 1000 bar, spray angle is increased for diesel, RME, and WCOME because of the difference in viscosity and surface tension. However, the spray angle increases as the injection pressure increases. The same observations are reported by (Delacourt, Desmet et al. 2005).

\section{Sauter Mean Diameter}

Figure 12 presents the relation between the SMD and the crank angle for diesel and the selected biofuels under the scope. The numerical results captured greater SMD of biodiesels than ordinary diesel, and spray was more concentrated, due to the higher viscosity and surface tension of the biodiesel, compared with conventional diesel fuel. It was consistent with previous experimental and simulation studies (Gao, Deng et al. 2009) and (Lee, Park et al. 2005). The higher viscosity, surface tension, and density are responsible for the larger SMD of biodiesels, where the viscosity is regarded to have the largest contribution to the change in SMD.

Hence, the reduction in the rate of burning fuel and velocity is logical as the diameter of the droplets increased. At 200 bar, while SMD for diesel is 17.4 microns, it was 20.385 for RME and 20.468 for WCOME. It is found that SMD is decreased for biodiesel and diesel as well because of the increase in the injection pressure; this is clearly explained in Figure 13. As the injection pressure increased from 200 bar to 1000 bar, the SMD is reduced by 59\%, $58 \%$, and $55.5 \%$ for diesel, RME, and WCOME, respectively. 


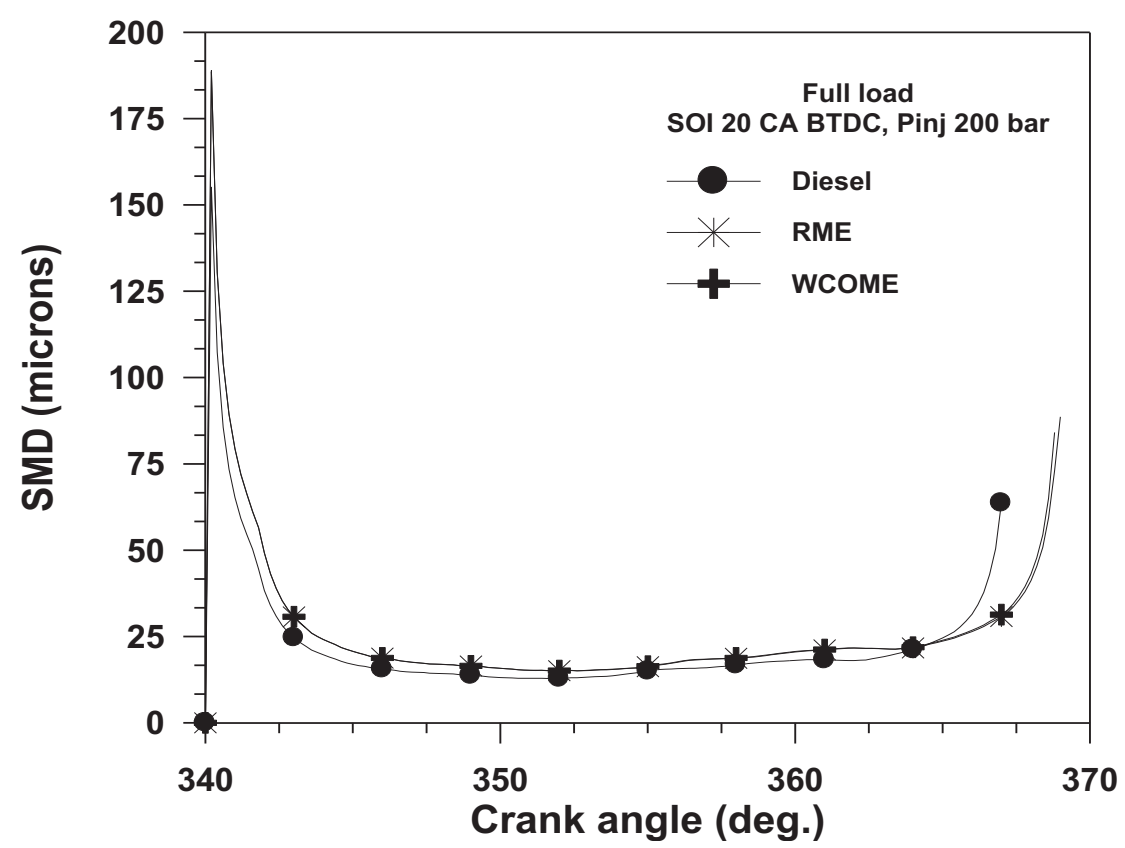

Figure 12. The SMD with crank angle for different fuels at 200 bar.

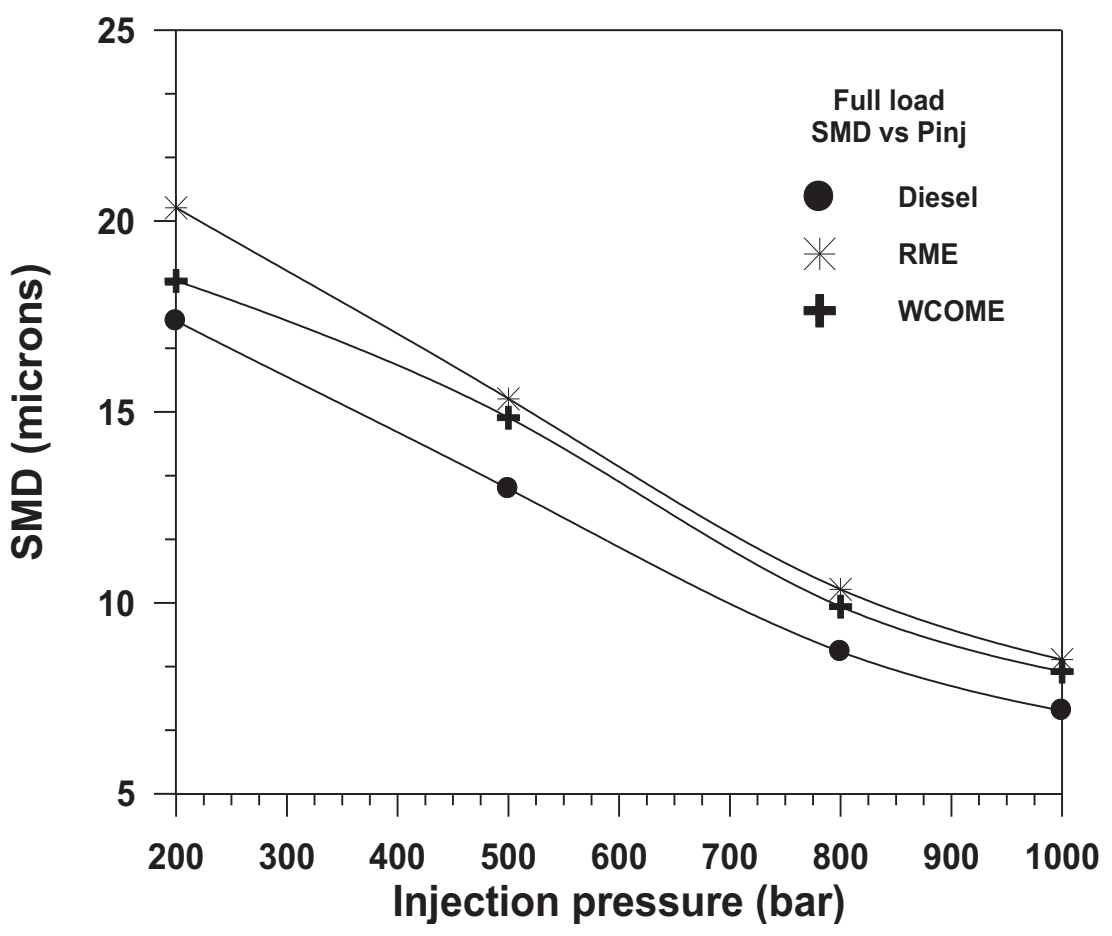

Figure 13. Effect of injection pressure on the SMD for different fuels. 


\section{Ignition Delay and Start of Combustion}

Since the spray characteristics of the fuel greatly influence the combustion and emissions characteristics of diesel engines, it plays a vital role in improving the combustion and emission characteristics of fuel because it directly affects the air-fuel mixture formation. The variation of the delay period with injection pressure is shown in Figure 14. The quality of ignition is frequently influenced by a cetane number; therefore, a high cetane number indicates shortly ignition delay. Since WCOME has a shorter delay period, hence, it is logically expected to start combustion before RME and diesel. This is shown in Figure 15. It is found that the combustion starts earlier with the increase in the pressure of injection. At 200 bar, while diesel starts to combust at $11^{\circ} \mathrm{CA} \mathrm{BTDC}$, the RME combusts at $17^{\circ} \mathrm{CA}$ BTDC, and WCOME combusts at $16.5^{\circ} \mathrm{CA}$ BTDC.

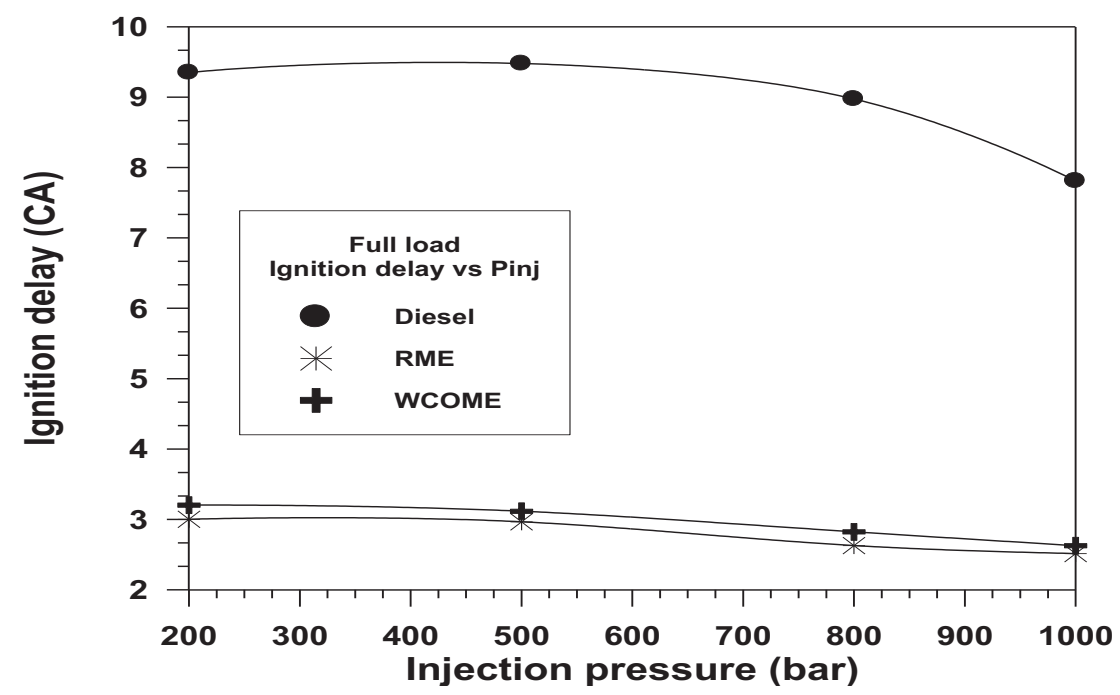

Figure 14. The ignition delay at different injection pressures for different types of fuels.

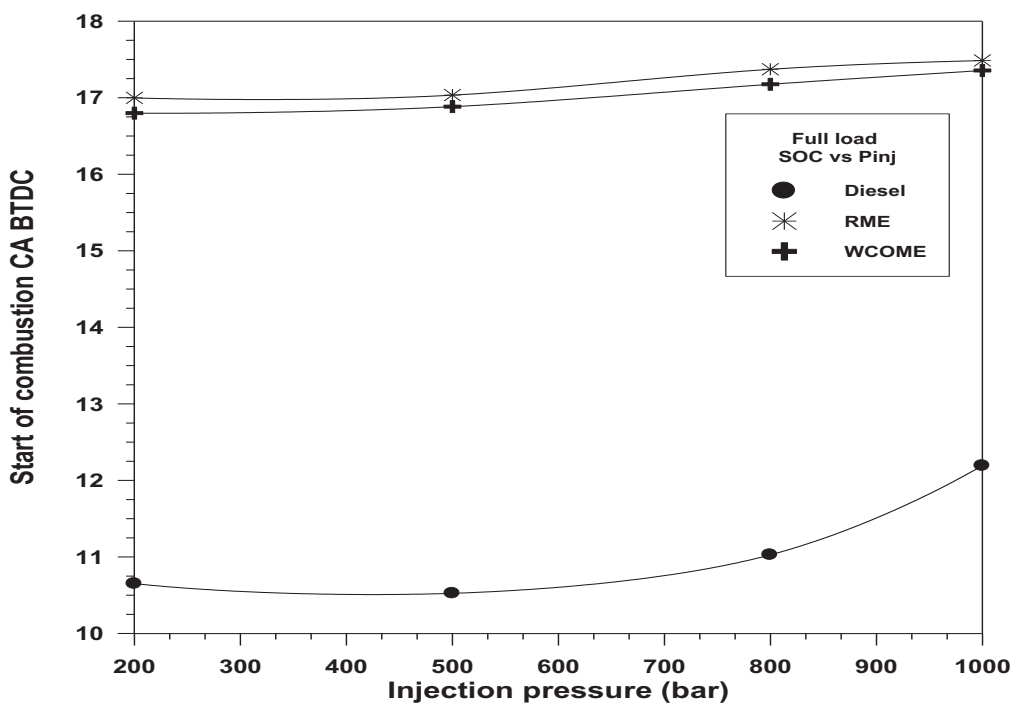

Figure 15. The SOC at different injection pressures for different types of fuels. 


\section{Cylinder Pressure and Heat Release Rate}

As previously mentioned, the structure of spray is directly affected by combustion and emission parameters; therefore, it is logical to display the effect using different biofuels on the cylinder pressure. Figure 16 displays the relation between cylinder pressure and crankshaft for diesel RME and WCOME. It is noted that the peak pressure for diesel is 102.44 bar, while it is 74.1 bar for RME and 79.32 bar WCOME, respectively, because of the reduction in the heat supply of tested biodiesel.

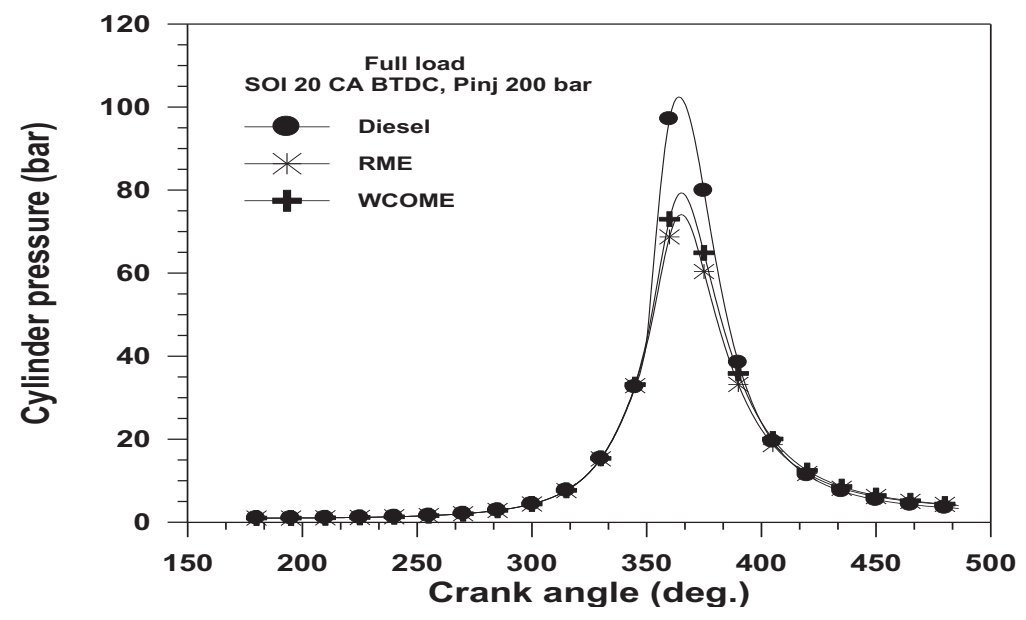

Figure 16. The cylinder pressure versus crank angles for different types of fuels.

Figure 17 Shows the history of heat release rate with the crank angle for diesel, RME, and WCOME. The biofuels had the earliest combustion start because of the time of injection advancement and a shorter delay period, which is clearly described in Figure 14. Since the heating value of diesel is higher than all biofuels understudy, hence, a higher rate of heat release is expected for diesel. Both RME and WCOME have almost the same behavior and the heat released comes with a slight difference.

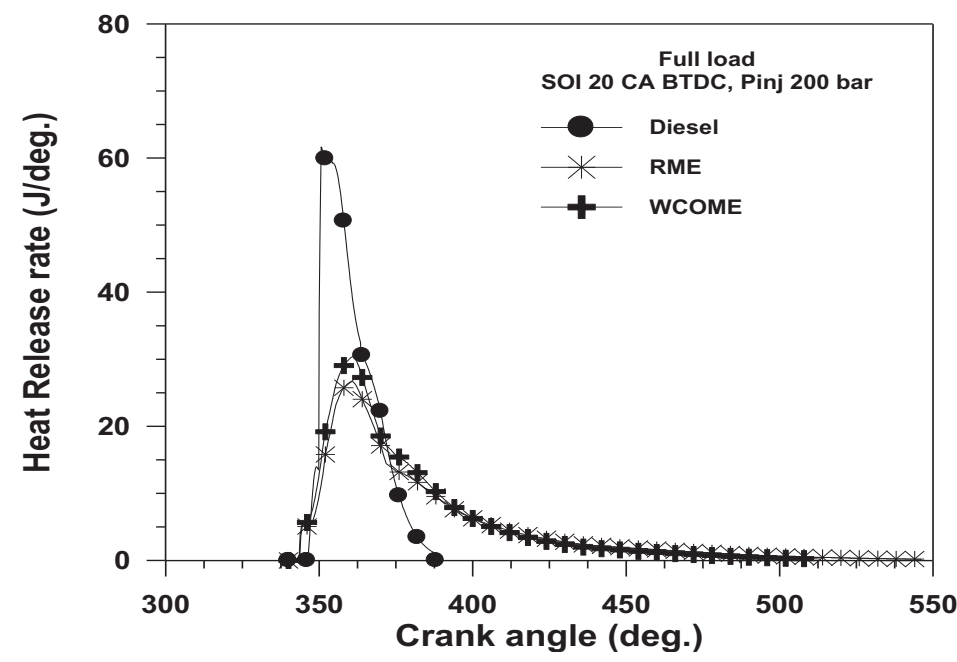

Figure 17. The heat release rate versus crank angles for different types of fuels. 


\section{Soot Emissions}

Figure 18 explains the relationship between the smoke concentration rate with the crank angle for diesel RME and WCOME. The lowest ability to produce smoke is recorded for WCOME, where 93\% reduction is achieved followed by a $57 \%$ reduction for RME as compared to diesel. The high oxygen capacity of biodiesel is responsible for soot reduction, which leads to complete oxidization; hence, the oxygen molecules in the fuel decrease the trend of fuel for the production of smoke (Öner and Altun 2009).

Besides all the figures discussed above and in order to follow the obtained results smoothly, some of the simulation results are reported in Table 3 (a-b-c-d) according to each injection pressure used.

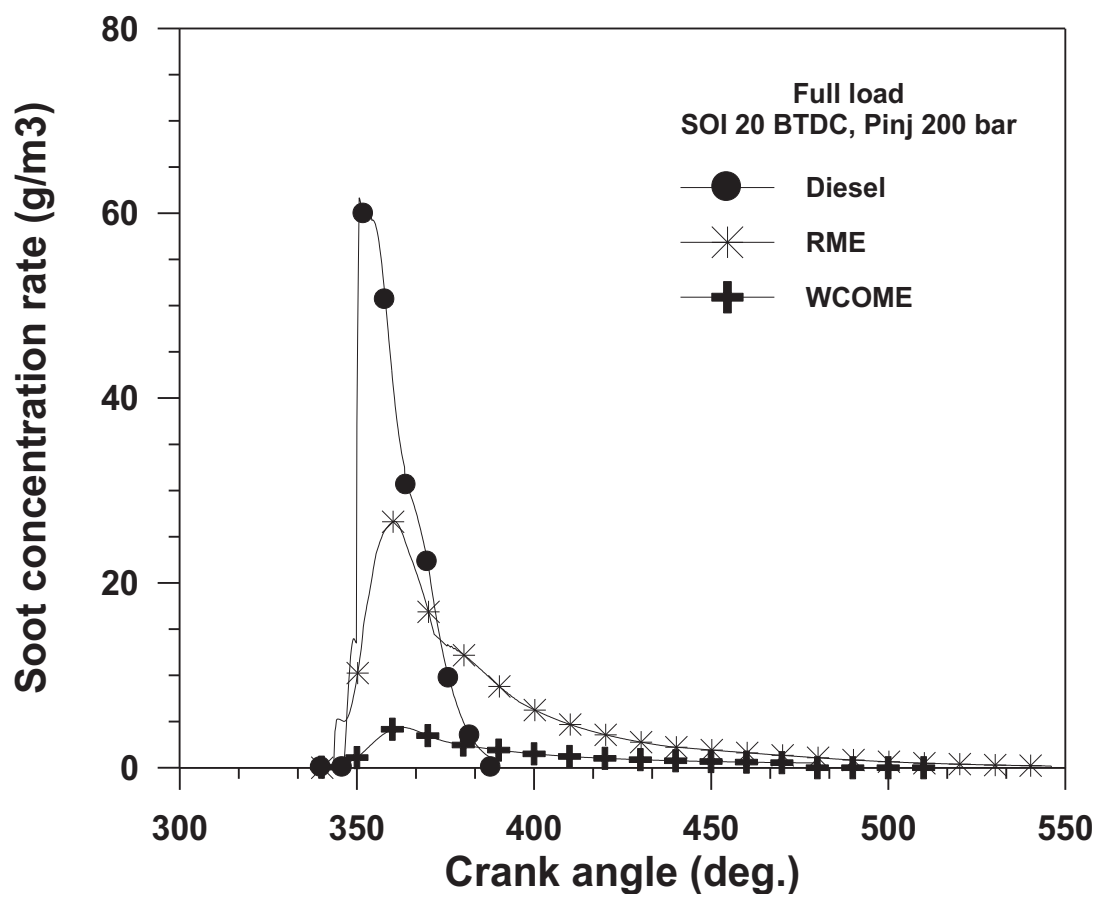

Figure 18. The soot concentration versus crank angles for different types of fuels.

Table 3. (a) Simulation results at 200 bar.

\begin{tabular}{|c|c|c|c|c|c|c|c|}
\hline Fuel & $\mathbf{P}_{\max } \mathbf{b a r}$ & $\mathbf{T}_{\max } \mathbf{K}$ & $\begin{array}{c}\text { SMD } \\
\mathbf{m i c r o n}\end{array}$ & $\begin{array}{c}\text { SOC CA } \\
\text { BTDC }\end{array}$ & IDP CA & NOx ppm & BSN \\
\hline Diesel & 102.44 & 2101.7 & 17.378 & 10.650 & 9.3495 & 3337.6 & 0.99422 \\
\hline WCOME & 79.214 & 1772.7 & 20.468 & 16.911 & 3.0894 & 2510.6 & 2.8246 \\
\hline RME & 74.177 & 1578.1 & 20.385 & 17.002 & 2.9977 & 1852.5 & 3.7439 \\
\hline
\end{tabular}


Table 3. (b) Simulation results at 500 bar.

\begin{tabular}{|c|c|c|c|c|c|c|c|}
\hline Fuel & $\mathbf{P}_{\max } \mathbf{b a r}$ & $\mathbf{T}_{\max } \mathbf{K}$ & $\begin{array}{c}\text { SMD } \\
\mathbf{m i c r o n}\end{array}$ & $\begin{array}{c}\text { SOC CA } \\
\text { BTDC }\end{array}$ & IDP CA & NOx ppm & BSN \\
\hline Diesel & 101.03 & 2070.3 & 12.990 & 10.586 & 9.4141 & 3150.9 & 1.3293 \\
\hline WCOME & 81.195 & 1753.9 & 15.377 & 16.885 & 3.1153 & 2469.1 & 2.8757 \\
\hline RME & 71.398 & 1577 & 15.341 & 17.036 & 2.9642 & 1704 & 3.7655 \\
\hline
\end{tabular}

Table 3. (c) Simulation results at 800 bar.

\begin{tabular}{|c|c|c|c|c|c|c|c|}
\hline Fuel & $\mathbf{P}_{\max }$ bar & $\mathbf{T}_{\max } \mathbf{K}$ & $\begin{array}{c}\text { SMD } \\
\mathbf{m i c r o n}\end{array}$ & $\begin{array}{c}\text { SOC CA } \\
\text { BTDC }\end{array}$ & IDP CA & NOx ppm & BSN \\
\hline Diesel & 89.583 & 1926.9 & 8.7136 & 11.026 & 8.9736 & 1685.6 & 2.3582 \\
\hline WCOME & 80.204 & 1774.3 & 10.359 & 17.177 & 2.8227 & 2030.8 & 2.7772 \\
\hline RME & 76.366 & 1718.2 & 10.351 & 17.373 & 2.6271 & 1704.7 & 3.0920 \\
\hline
\end{tabular}

Table 3. (d) Simulation results at 1000 bar.

\begin{tabular}{|c|c|c|c|c|c|c|c|}
\hline Fuel & $\mathbf{P}_{\max } \mathbf{b a r}$ & $\mathbf{T}_{\max } \mathbf{K}$ & $\begin{array}{c}\text { SMD } \\
\mathbf{m i c r o n}\end{array}$ & $\begin{array}{c}\text { SOC CA } \\
\text { BTDC }\end{array}$ & IDP CA & NOx ppm & BSN \\
\hline Diesel & 92.515 & 1984.7 & 7.1719 & 12.191 & 7.8091 & 1974.4 & 2.1514 \\
\hline WCOME & 82.073 & 1818.2 & 8.5267 & 17.375 & 2.6246 & 2212.1 & 2.4891 \\
\hline RME & 76.727 & 1736.5 & 8.5142 & 17.487 & 2.5128 & 1784.4 & 3.00010 \\
\hline
\end{tabular}




\section{CONCLUSION}

Numerical macroscopic spray characteristics of diesel and biodiesels have been performed at different injection pressures. According to the results of this study, the following conclusions can be established:

1. Larger spray penetration of biodiesels with smaller spray cone angle compared to diesel is observed because of higher density surface tension and viscosity.

2. No matter which biodiesel is used, as the injection pressure increases, spray penetration is increased.

3. The variation of injection pressure does not come with a noticeable effect on the spray angle.

4. Both RME and WCOME have greater SMD than diesel, and a promising reduction in SMD is found out when injection pressure increased.

5. The combustion characteristics in terms of heat release and cylinder pressure are reduced in the cases of RME and WCOME due to the reduction in heating values.

6. Dramatic reduction in the smoke concentration rate was recorded for WCOME, and then RME comes, followed by diesel.

\section{REFERENCES}

Srinidhia C., Madhusudhanb A. \& Channapattana S.V.(2019)." Effect of NiO nanoparticles on performance and emission characteristics at various injection timings using biodiesel-diesel blends". Fuel. 235:185-193.

Srinidhi C. \& Madhusudhan A. (2017). "A Diesel Engine Performance Investigation Fuelled with Nickel Oxide Nano Fuel-methyl Ester".International journal of renewable energy research. 7(2):676-681

Senthil kumar D. \& Thirumalini S. (2020)." Investigations on effect of split and retarded injection on the performance characteristics of engines with cashew nut shell biodiesel blends". Internation joural of ambient energy https://doi.org/10.1080/01430750.2020.1730961.

Srinidhia C., Madhusudhanb A. \& Channapattana S.V.(2019)." Comparative analysis of Exhaust Gas Recirculation and Nanoparticles on the Performance and emission of Diesel Engine fuelled with Neem Biodiesel Blend. International journal of ambient energy https://doi.org/10.1080/01430750.2019.1636876

Ahmed, M., C. Ejim, B. Fleck \& A. Amirfazli (2006). "Effect of biodiesel fuel properties and its blends on atomization", SAE Technical Paper. 2006-01-0893, doi:10.4271/2006-01-0893.

Al-Dawody, M. (2006). "Modeling of a four stoke diesel engine operated with hydrogen blended fuel", M.Sc theis, University of Babylon.

Al-Dawody, M. F., Ali A. Jazie \& H. A. J. A. E. J. Abbas (2019). "Experimental and simulation study for the effect of waste cooking oil methyl ester blended with diesel fuel on the performance and emissions of diesel engine." Alexandria engineering journal 58(1): 9-17.

Al-Dawody M. F. (2013)."Experimental and theoretical investigations on combustion, performance and emissions of diesel engine fueled with diesel-biodiesel blends", Ph.D thesis Department of Mechanical Engineering, Andhra University.

Al-Dawody, M. F. (2017). "Theoretical study for the influence of biodiesel addition on the combustion, performance and emissions parameters of single cylinder diesel engine." Journal of babylon university/Engineering sciences 25(5): 1830-1839.

Alkidas, A. (1984). "Relationship between smoke measurements and particulate measurements", SAE Technical paper 840412.

Arrègle, J., J. V. Pastor \& S. Ruiz (1999). "The influence of injection parameters on diesel spray characteristics", SAE Technical paper. 1999-01-0200 
Bracco, F. J. S. t. (1981). "Modeling of engine sprays." SAE Paper No. 850394, 144-167.

Delacourt, E., Desmet B. \& Besson B. (2005). "Characterisation of very high pressure diesel sprays using digital imaging techniques." Fuel. 84 (7-8): 859-867.

Deng, J., C. Li, Z. Hu, Z. Wu \& L. Li (2010). "Spray characteristics of biodiesel and diesel fuels under high injection pressure with a common rail system", SAE Technical Paper. 2010-01-2268

Ejim, C., Fleck B.\& Amirfazli A. J. F. (2007). "Analytical study for atomization of biodiesels and their blends in a typical injector: surface tension and viscosity effects." Fuel. 86(10-11): 1534-1544.

Gao, Y., Deng J., Li C., Dang F., Liao Z., Wu Z. \& Li L. (2009). "Experimental study of the spray characteristics of biodiesel based on inedible oil." Biotechnology advances 27(5): 616-624.

Grimaldi, C. \& Postrioti L. (2000). "Experimental comparison between conventional and bio-derived fuels sprays from a common rail injection system." SAE Technical Paper 2000-01-1252, 1501-1513.

Hiroyasu, H. \&. Arai M (1990). "Structures of fuel sprays in diesel engines." SAE Technical Paper 900475, 1050-1061.

Hiroyasu, H. Kadota, T., \& Arai, M. (1980). "Supplementary comments: fuel spray characterization in diesel engines." Plenum Press, NewYork, 369-408.

Jia, T.-M., G.-X. Li, Y.-S. Yu, Y.-J. J. E. T. Xu \& F. Science (2016). "Effects of ultra-high injection pressure on penetration characteristics of diesel spray and a two-mode leading edge shock wave." Experimental Thermal and Fluid Science 79: 126-133.

Jung, D. \& Assanis, D (2001). "Multi-zone DI diesel spray combustion model for cycle simulation studies of engine performance and emissions." SAE paper No. 2001-01-1246, 1510-1532.

Kuleshov, A. (2005). Model for predicting air-fuel mixing, combustion and emissions in DI diesel engines over whole operating range, SAE paper No. 2005-01-2119.

Mahkamov K, \& Kuleshov, A. (2008). "Multi-zone diesel fuel spray combustion model for the simulation of a diesel engine running on biofuel." Proceeding Institute of mechanical engineers part A Journal of power and energy: 222(3): 309-321.

Kuo, T.-W. \& Bracco F. (1982). "On the scaling of transient laminar, turbulent, and spray jets", SAE Technical Paper 820038.

Lacour, S., Raoult F., Tinet C., Fournaison L., Delahaye A., Trinquet \& Science F. (2019). "A modal analysis of the size distribution for an hollow-cone spray in cross-flow." Experimental Thermal and Fluid Science 104: $164-174$.

Larmi, M., P. Rantanen, J. Tiainen, J. Kiijärvi, F. X. Tanner and K. Stalsberg-Zarling (2002). "Simulation of non-evaporating diesel sprays and verification with experimental data", SAE Technical Paper. 2002-010946.

Lee, C.S., Park, S.W., \& Kwon, S.I. (2005). "An experimental study on the atomization and combustion characteristics of biodiesel-blended fuels." energy and fuels 19(5): 2201-2208.

Mohan, B., Yang W., Tay K. L., Yu W.\& science f. (2014). "Macroscopic spray characterization under high ambient density conditions.". Experimental Thermal and Fluid Science 59: 109-117.

Nakagawa, H., Oda Y., Kato S., Nakashima M.\& Tateishi M. (1990). Fuel spray motion in side injection combustion system for diesel engines. Proceedings of the International Symposium COMODIA, pp. 281286.

Öner, C. \& Altun Ş. (2009). "Biodiesel production from inedible animal tallow and an experimental investigation of its use as alternative fuel in a direct injection diesel engine." Applied energy 86(10): 2114-2120. 
Pastor, J. V., Encabo, E., \& Ruiz, S. (2000). New modelling approach for fast online calculations in sprays, SAE paper No.2000-01-0287.

Payri, F., Bardi M., Carreres M.\& science f. (2014). "Engine combustion network: Influence of the gas properties on the spray penetration and spreading angle." Experimental Thermal and Fluid Science,. 53: 236243.

Senatore, A., Cardone M., Allocca L., Vitolo S. \& Rocco V. (2005). Experimental characterization of a common rail engine fuelled with different biodiesel, SAE Technical Paper. 2005-01-2207

Xusheng, Z., Liguang L.\&. Jun D. (2007). "An experimental study of bio-diesel spray characteristics." Trans. CSICE, 25(2): 172-176.

Zhao, X., Han X., He C.\& Tan E. (2008). "Experimental study on spray characteristics of biodiesel oil." Chin Intern Combust Engine Eng, 1:9-16. 